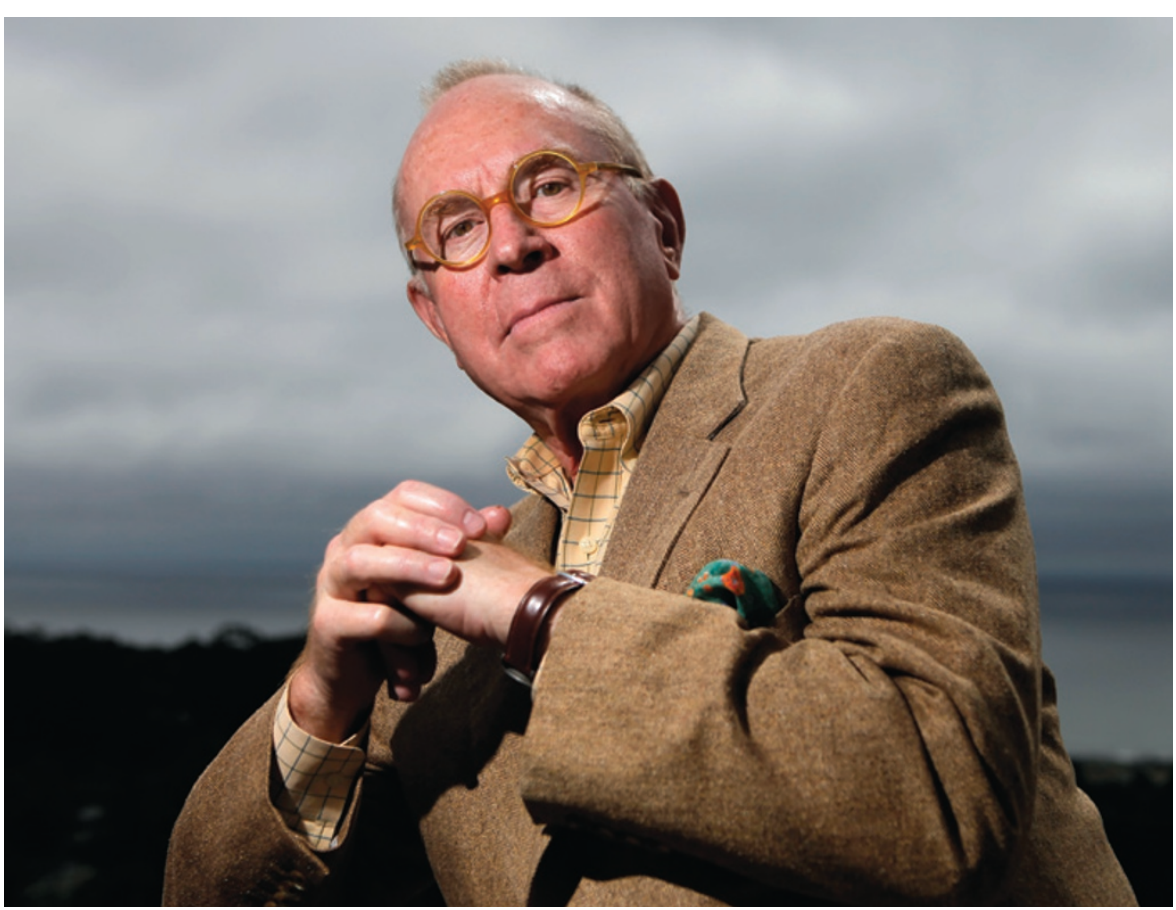

Q\&A Richard Rhodes

\title{
Chronicler of conflict
}

Historian Richard Rhodes writes on the roots of violence and warfare, in particular the development of nuclear weapons. He talks about Reykjavik - his play on nuclear disarmament - and his upcoming book on the Spanish Civil War, That Fine Place.

\section{What drew you to write about conflict?}

An early encounter with violence - a stepmother who abused and starved my older brother and me. Fortunately, when I was 12 and he was 13 , my brother had the courage to go to the police. We were removed to a private boys' home on a farm near Independence, Missouri. I gained 14 kilos in three months. There was something immensely healing about the natural processes that sustained us on that farm, from planting potatoes to butchering animals.

\section{What happened next?}

I thought I would become a Methodist minister, but later, while studying philosophy at Yale University, I realized I could think about moral issues without the metaphysical superstructure. I eventually found my calling as an independent historian.

\section{How did you come to write about nuclear weapons?}

Growing up during the Second World War, I was aware that the first use of atomic bombs marked a millennial change in human affairs. In 1976, I received a Guggenheim Fellowship to write a novel based on the true story of a scientist at a government lab - perhaps Los
A free staged reading of Reykjavik Plan B Theatre, Salt Lake City, Utah. 24 June

That Fine Place

Simon \& Schuster: 2014

Alamos - who had constructed an elaborate fantasy world where he was an intergalactic hero. I realized that fiction wasn't the right medium for the story of nuclear weapons. Around 1975, the US government declassified an enormous number of documents relating to the Manhattan Project. This convinced me that I should write a serious history of the first atomic bombs. That became the first book in my series, The Making of the Nuclear Age.

\section{Why did you write a play on nuclear disarmament?}

Reykjavik is an attempt to convey the potential for nuclear disarmament to a new audience. Deterrence was a sham. We had a dozen near-cataclysms during the cold war. Some, such as the Cuban missile crisis, we've heard about; some we haven't. What saved us was sheer dumb luck, and we're still living on borrowed time. Ronald Reagan and Mikhail Gorbachev, for very different reasons, both wanted to eliminate nuclear weapons. At the
1986 Reykjavik summit, they came within a hair's breadth of agreeing to move toward nuclear abolition.

\section{What is the future for nuclear-arms} reduction?

Eventually a nuclear weapon will go off, and either people will start rearming out of fear, or we will all wake up. A 2007 study found that even a small nuclear exchange between, say, India and Pakistan could create a cloud of soot from mass fires that would reduce the global average temperature by $1-1.5^{\circ} \mathrm{C}$, enough to produce agricultural collapse and cause a billion deaths from starvation. When we understand that the weapons themselves are the danger, and not the politics or the morals of those who control them, we'll be well on our way to eliminating them.

\section{What do you explore in That Fine Place?}

In a way, it is a prehistory of our current technologies for killing human beings. Time magazine called the Spanish Civil War a "little world war" because so many countries were involved. Certainly it served as a test bed for the killing technologies of the Second World War. The German Condor Legion, whose firebombing of Guernica is memorialized in Picasso's painting, was the first to systematically carpet-bomb cities. Terror bombing came back to haunt the Germans during the Second World War with the Allied firebombings of cities such as Dresden.

\section{What medical advances were made during the Spanish Civil War?}

There were breakthroughs in bone casting and wound surgery that reduced casualties from infection. On a trip to Spain, I saw a shallow cave in a narrow valley that had been turned into a 120-bed hospital. It was a dark, cold place, but it had a spring of fresh water, and Franco's planes couldn't bomb it. I also came across an extraordinary photograph of a dozen litres of blood ready to be transported to the front - in sterile wine and milk bottles.

\section{What military innovations will our era be remembered for?}

The most interesting consequences of technology are usually unintended. Nuclear weapons were supposed to increase states' power. Instead, they limited it to minor wars. The Internet was going to protect US military communications in case of nuclear war. Instead, it opened up the world. One promising trend is the rise of spontaneous citizen surveillance to monitor the development of clandestine weapons. In 1944, Niels Bohr predicted that to control proliferation you'd need total transparency. The more people with camera phones in their hands, the easier it will be to police the world's arsenals. 